\title{
PENANAMAN KONSEP GENDER PADA MATA PELAJARAN IPS SD
}

\author{
Fitria Martanti \\ Fakultas Agama Islam Universitas Wahid Hasyim \\ Semarang \\ f.martanti@gmail.com
}

\begin{abstract}
Abstrak
Konsep gender yang benar semestinya diajarkan pada anak mulai usia dini maupun usia sekolah dasar. Pemahaman gender akan memberikan gambaran tentang peran laki-laki dan perempuan yang benar bukan hanya sekedar stereotip masyarakat. Penanaman konsep gender yang tidak sesuai akan membentuk pemikiran anak tetang bagaimana peran laki-laki dan perempuan dan akan membentuk pemikiran anak yang bias gender. Adanya stereotip tentang gender pada dasarnya sangat nampak dalam pendidikan terutama nilai gender yang dianut oleh masyarakat terutama berkaitan dengan tempat pendidikan diabdikan, stereotip gender yang terdapat dalam kurikulum maupun buku ajar, dan nilai gender yang ditanamkan oleh guru. Menginggat begitu pentingnya penanaman konsep gender yang benar pada anak, maka dapat dilakukan melalui beberapa cara diantaranya penanaman konsep gender dalam mata pelajaran Ilmu Pengetahuan Sosial (IPS). Hal ini menginggat mata pelajaran IPS SD memiliki muatan materi untuk memahamkan anak tentang diri sendiri, keluarga dan masyarakat. Adapun konsep gender tentunya dapat diajarkan guru pada mata pelajaran IPS tema keluarga. Peran guru harus dapat memberikan contoh konkrit tentang peran laki-laki dan perempuan dalam keluarga, sekolah maupun masyarakat sehingga anak akan memahami konsep gender yang benar.
\end{abstract}

Kata kunci: Konsep Gender, Pelajaran IPS

\begin{abstract}
The appropriate gender concept should be taught on children since early childhood or elementary school age. The understanding of gender will give description about the appropriate act on men and women, not only public stereotype. Unappropriate gender implementation will shape children's mind about how men and women act and will shape children's mind which gender refraction. The existance of stereotype about gender basically is visible in education, especially gender value attentived by public and related to implementation place, gender stereotype available in curriculum or teaching book, and gender value which applied by teacher. Considering the importance of appropriate gender implementation on children, it can be done by some ways, such as gender concept implementation in IPS lesson. Because it consider
\end{abstract}


that IPS lesson on elementary school has material to understand student about themselves, family, and public. Gender concept can be taught by teacher on IPS lesson in theme about family. Teacher role should be give solid model about men and women act in family, school, and public so students can understand the appropriate gender concept.

Keywords: gender concept, IPS lesson

\section{A. PENDAHULUAN}

Pemahaman gender diidentikkan dengan peran laki-laki dan perempuan. Banyak orang yang salah memahami konsep gender justru berawal dari penanaman konsep gender di sekolah. Guru maupun sumber belajar yang digunakan dalam proses pembelajaran justru memberikan gambaran peran laki-laki dan perempuan bukan yang sebenarnya tapi yang umumnya berkembang di masyarakat. Sekolah pada dasarnya bukan hanya organisasi yang berperan sebagai transfer keilmuan, melainkan juga merupakan sarana sosialisasi dan internalisasi nilai (kebudayaan) yang dalam prosesnya berlangsung secara formal, termasuk nilai dan norma gender. ${ }^{1}$ Keberadaan sekolah terutama guru yang secara langsung berinteraksi dengan siswa dirasa cukup penting untuk dapat memahamkan konsep yang benar tentang gender itu sendiri. Guru dapat memahamkan konsep gender melalui integrasi contoh kongkrit dalam mata pelajaran yang diajarkan. Salah satu mata pelajaran yang memberikan materi tentang keluarga dan peran anggota keluarga adalah mata pelajaran Ilmu Pengetahuan Sosial (IPS), sehingga dalam penanaman konsep gender dapat terintegrasi pada mata pelajaran Ilmu Pengetahuan Sosial.

Ilmu Pengetahuan Sosial sebagai salah satu mata pelajaran yang mengajarkan tentang keluarga dan peran anggota keluarga tentunya sangat

1 Achmad Muthaliin, Bias Gender dalam Pendidikan, Surakarta: Muhamadiyah University Press, 2001, hlm.56 
berperan penting dalam menanamkan konsep gender yang benar bagi siswa. Materi Ilmu Pengetahuan Sosial SD sarat dengan pemahaman bagaimana siswa memahami tentang diri sendiri, keluarga maupun masyarakat. Pembelajaran Ilmu Pengetahuan Sosial memiliki fungsi untuk mentransmisikan pengetahuan dan pemahaman tentang masyarakat berupa konsep, fakta-fakta maupun peristiwa kepada siswa. Ilmu Pengetahuan Sosial merupakan salah satu mata pelajaran yang dapat digunakan untuk mengarahkan dan membimbing siswa untuk menjadi warga negara Indonesia dan warga dunia yang demokratis. Hal ini merupakan tantangan berat karena masyarakat global selalu mengalami perubahan setiap saat. Ilmu Pengetahuan Sosial dirancang untuk membangun dan merefleksikan kemampuan siswa dalam kehidupan bermasyarakat yang selalu berubah dan berkembang secara terus menerus. Pembelajaran IPS tidak hanya menuntut siswa untuk memahami apa yang telah dipelajari, tetapi juga harus mampu memberikan contoh-contoh sosial yang nyata di lingkungan masyarakat seputar materi yang disampaikan. Hal ini berguna untuk membawa keberhasilan bagi siswa dalam bermasyarakat dan proses menuju kedewasaan.

Ilmu Pengetahuan Sosial memuat beberapa tujuan pokok dari pengajaran yaitu: (a) mengenal konsep-konsep yang berkaitan dengan kehidupan masyarakat dan lingkungannya; (b) memiliki kemampuan dasar untuk berfikir logis dan kritis, rasa ingin tahu, inkuiri, memecahkan masalah dan keterampilan dalam kehidupan sosial; (c) memiliki komitmen dan kesadaran terhadap nilai-nilai sosial dan kemanusiaan; (d) memiliki kemampuan berkomunikasi, bekerjasama dan berkompetisi dalam masyarakat yang majemuk, di tingkat lokal, nasional dan global. ${ }^{2}$

2 Sapriya, Pendidikan IPS, Bandung: PT Remaja Rosdakarya, 2009, hlm.194-195 
Bias gender merupakan sebuah realitas kehidupan yang mengunggulkan satu jenis kelamin tertentu dan merendahkan jenis kelamin lainnya, sehingga menyebabkan adanya ketimpangan gender. Berbagai bentuk kesenjangan gender yang terjadi dalam berbagai bidang kehidupan masyarakat, juga nampak jelas dalam dunia pendidikan, bahkan proses dan institusi pendidikan dipandang berperan besar dalam mensosialisasikan dan melestrikan nilai-nilai dan cara pandang yang mendasari munculnya berbagai ketimpangan gender dalam masyarakat. ${ }^{3}$

Pendidikan selayaknya mampu memandang manusia tanpa melihat jenis kelamin manusia tersebut. Hal ini karena pendidikan yang tidak diskriminatif tentunya akan menguntungkan bagi laki-laki maupun perempuan, dan pada akhirnya akan mempermudah terjadinya kesetaraan dalam hubungan antara laki-laki dan perempuan. Pendidikan pada dasarnya dapat digunakan sebagai instrumen untuk mentransfer nilai-nilai hidup termasuk nilai yang berkaitan dengan isu gender. Dengan demikian pendidikan juga sarana sosialisasi kebudayaan yang berlangsung secara formal termasuk di sekolah.

Memperhatikan esensi yang terkandung dalam mata pelajaran Ilmu Pengetahuan Sosial, maka pembelajaran di sekolah seharusnya merupakan suatu kegiatan yang disenangi dan bermakna bagi siswa. Pembelajaran yang menyenangkan akan menyebabkan siswa terlibat secara aktif. Dengan terlihat aktif, maka siswa akan mempunyai pemahaman yang kuat terhadap materi. Oleh karena itu, guru dituntut untuk dapat mengelola proses belajar mengajar dengan memiliki kemampuan dalam memilih model dan metode pembelajaran yang sesuai dengan tujuan kurikulum dan potensi yang dimiliki oleh peserta didik. Hal ini didasari oleh asumsi bahwa ketepatan

\footnotetext{
${ }^{3}$ Hanun, Asrohah, Sosiologi Pendidikan, Surabaya: Kopertais Press, 2008, hlm 178.
} 
guru dalam memilih model dan metode pembelajaran akan berpengaruh terhadap hasil belajar peserta didik, karena hasil belajar siswa merupakan salah satu indikator keberhasilan proses belajar mengajar di kelas

Menghadapi tuntutan situasi perkembangan zaman dan pembangunan nasional, sistem pendidikan nasional harus dapat dilaksanakan secara tepat guna dalam berbagai aspek, dimensi, jenjang, dan tingkat pendidikan. Guru berperan sebagai fasilitator dalam pelaksanaan pendidikan mampu memberikan kemudahan kepada anak didiknya untuk mempelajari berbagai hal dengan menggunakan sumber belajar yang efektif dan efisien, terutama yang ada di lingkungan sekitar, sehingga diharapkan akan tumbuh minat yang tinggi pada siswa. Pada anak usia SD memiliki stereotype gender yang sangat kuat akibat sosialisasi pelabelan gender yang membedakan antara laki-laki dan perempuan. Laki-laki dilabelkan sebagai sosok yang sangat kuat, sehingga apabila ada anak laki-laki yang menangis pasti diejek oleh teman-teman sebagai anak cengeng, sebaliknya perempuan adalah orang yang lemah lembut sehingga apabila ada anak perempuan yang bertengkar pasti dipanggil dengan sebutan anak tomboy. Pada anak usia tersebut perlu mendapatkan gambaran tentang apa yang berkaitan dengan konsep gender, sehingga guru harus memberikan konsep dan gambaran konkrit tentang kesetaraan gender agar siswa tidak mengalami bias gender.

Bias gender nampak dalam realita kehidupan baik di lingkungan masyarakat maupun lingkungan sekolah. Fakta menunjukkan bahwa anak perempuan diarahkan untuk selalu tampil cantik, lemah-lembut, dan melayani, sementara laki-laki diarahkan untuk tampil gagah, kuat, dan berani. Bias gender tersebut tentunya berawal dari adanya aturan-aturan tertentu yang dituntut oleh masyarakat terhadap laki-laki maupun perempuan. Jika perempuan tidak dapat memenuhi aturan masyarakat, 
maka ia akan disebut perempuan tidak baik, tidak tahu adat dan kasar. Demikian pula jika laki-laki tidak dapat memenuhi aturan yang ditetapkan masyarakat maka laki-laki tersebut akan disebut sebagai laki-laki lemah, banci, penakut atau bukan lelaki sejati. Melihat realita tersebut maka pemahaman tentang peran dan aturan bagi laki-laki maupun perempuan perlu ditatamkan mulai dari penanaman konsep gender yang benar melalui mata pelajaran yang diajarkan oleh guru di kelas.

\section{B. PEMAHAMAN TENTANG KONSEP GENDER}

Sebagian besar masyarakat masih banyak yang belum bisa membedakan antara konsep gender dan jenis kelamin, sehingga tidak jarang kedua terminologi tersebut secara konseptual dianggap sama. Istilah jenis kelamin dan gender memiliki pengertian yang sama sekali berbeda. ${ }^{4}$ Adanya kesalahan dalam memahami makna gender tentunya akan menyebabkan sikap menentang atau sulit bisa menerima analisis gender dalam memecahkan berbagai masalah yang berkaitan dengan ketidakadilan sosial.

Jenis kelamin (sex) merupakan suatu konsep yang digunakan untuk melihat perbedaan laki-laki dan perempuan yang berdasar atas anatomi biologis dan merupakan kodrat Tuhan. ${ }^{5}$ Sex ini berarti jenis kelamin yang merupakan penyifatan atau pembagian jenis kelamin yang ditentukan secara biologis dan melekat pada jenis kelamin tertentu. Perbedaan anatomi biologis ini tidak dapat diubah dan bersifat menetap, kodrat dan

${ }^{4}$ Wawan Djunaedi, dan Iklilah Muzayyanah. 2008. Pendidikan Islam Adil Gender di Madrasah. Jakarta: Pustaka STAINU, 2008, hlm. 3

5 Nasarudin Umar, Argumen Kesetaraan Gender: Perspektif alQur'an.Jakarta :Paramadina, 2001, hlm. 1. 
tidak dapat ditukar. Oleh karena itu perbedaan tersebut berlaku sepanjang zaman dan di mana saja. ${ }^{6}$

Secara terminologis, makna jenis kelamin (sex) adalah perbedaan fisik yang didasarkan pada anatomi biologi manusia, terutama yang berhubungan dengan fungsi reproduksi. Berdasarkan perbedaan fisik dan biologis inilah dapat teridentifikasi dua jenis kelamin manusia, yaitu lakilaki dan perempuan. Perbedaan antara perempuan dan laki-laki murni harus didasarkan pada fungsi organ reproduksi yang kodrati dan bersifat alamiah (nature). Karena didasarkan pada perbedaan yang bersifat alamiah, perbedaan jenis kelamin berlaku secara universial bagi semua perempuan dan laki-laki di dunia. ${ }^{7}$

Gender adalah suatu sifat yang melekat pada laki-laki dan perempuan karena dikonstruksikan secara sosial dan kultural. Konsep gender berbeda dari konsep kodrat. Konsep gender adalah konstruksi sosial budaya tentang peran laki-laki dan peran perempuan yang bisa berubah dari waktu, tempat dan budaya yang berbeda. Gender biasanya dipahami masyarakat sebagai kesetaraan antara laki-laki dan perempuan terutama dalam dunia pendidikan, misalnya dalam masyarakat seorang anak laki-laki lebih diutamakan dalam menempuh pendidikan setinggi mungkin karena anak laki-laki akan menjadi kepala rumah tangga dan bertanggung jawab atas keluarganya. Sedangkan anak perempuan tidak diutamakan dalam menempuh pendidikan tinggi, karena anak perempuan kelak akan menjadi

6 Faqih Mansour, Analisis gender dan Transformasi Sosial. Yogyakarta: Pustaka Pelajar, 2000, hlm.8.

7 Wawan Djunaedi, dan Iklilah Muzayyanah, Pendidikan Islam Adil Gender di Madrasah. Jakarta: Pustaka STAINU, 2008, hlm. 4-5 
ibu rumah tangga yang bertugas mengurus pekerjaan rumah dan mengurus anak. $^{8}$

Gender adalah pembedaan peran, fungsi dan tanggung jawab antara perempuan dan laki -laki yang dihasilkan dari konstruksi sosial budaya dan dapat berubah sesuai dengan perkembangan zaman.9 Secara etimologis gender berasal dari kata gender yang berarti jenis kelamin, ${ }^{10}$ tetapi gender merupakan perbedaan jenis kelamin yang bukan disebabkan oleh perbedaan biologis dan bukan kodrat Tuhan, melainkan diciptakan baik oleh laki-laki maupun perempuan melalui proses sosial budaya yang panjang. Perbedaan perilaku antara pria dan wanita, selain disebabkan oleh faktor biologis sebagian besar justru terbentuk melalui proses sosial dan kultural. Gender dapat berubah dari tempat ketempat, waktu ke waktu, bahkan antar kelas sosial ekonomi masyarat.11 Dengan demikian, seks dipandang sebagai status yang melekat atau bawaan sedangkan gender sebagai status yang diterima atau diperoleh.

Gender dapat digunakan dalam menempatkan posisi setara antara laki-laki dan perempuan untuk mewujudkan tatanan masyarakat sosial yang lebih adil. Dengan demikian gender bukan hanya ditujukan kepada perempuan semata, tetapi juga kepada laki-laki, hanya saja yang dianggap mengalami posisi termarginalkan sekarang adalah pihak perempuan, maka perempuanlah yang lebih ditonjolkan dalam pembahasan untuk mengejar

${ }^{8}$ Marhaeni, A. A. I. N, Perkembangan Studi Perempuan, Kritik, dan Gagasan Sebuah Perspektif untuk Studi Gender ke Depan. Jurnal Piramida dalam ejournal. unud.ac.id, 2008, diakses 15 Agustus 2017.

9 Mufidah Ch. Bingkai Sosial Gender: Islam, Strukturasi dan Konstruksi Sosial. Malang: UIN Maliki Press, 2010, hlm. 5.

10 Jhon M. Echol, dan Hasan Shadily, Kamus Besar Inggris-Indonesia, Jakarta: Gramedia Pustaka Utama, 2000.

11 Riant Nugroho, Gender dan Administrasi Publik, Yogyakarta: Pustaka Pelajar, 2008, hlm.18. 
kesetaraan gender yang telah diraih oleh laki-laki beberapa tingkat dalam peran sosial, terutama di bidang pendidikan karena bidang inilah diharapkan dapat mendorong perubahan kerangka berpikir, bertindak, dan berperan dalam berbagai segmen kehidupan sosial.

\section{PEMBAHASAN}

Pembedaan peran, fungsi dan tanggung jawab laki-laki dan perempuan dalam konteks sosial pada dasarnya merupakan hal yang menguntungkan, akan tetapi dalam kenyataannya terjadi suatu ketimpangan gender dan hal tersebut merupakan penyebab munculnya salah satu jenis kelamin terabaikan hak dasarnya, tertinggal dan mengalami masalah ketidakadilan. ${ }^{12}$ deskriminasi gender ini nampak dalam berbagai bentuk sebagai berikut: 13

1. Stereotype adalah pelabelan terhadap jenis kelamin laki-laki atau perempuan yang berkonotasi positif atau negatif. Pelabelan memang merupakan suatu hal yang umum terjadi di masyarakat, sebagai contohnya bila seorang laki-laki bekerja hingga larut malam maka hal tersebut dianggap sebagai suatu hal yang biasa, akan tetapi bila hal demikian terjadi pada perempuan maka masyarakat akan memberikan stereotype bahwa perempuan tersebut bukan perempuan yang baik-baik.

2. Subordination adalah perlakuan menomorduakan yang mengakibatkan seseorang menempati posisi yang lebih rendah dibandingkan orang lain, sehingga tidak mendapatkan prioritas. Subordination merupakan suatu perlakuan yang secara sadar atau tidak sadar memang sudah dilakukan

12 Mufidah Ch, Bingkai Sosial Gender: Islam, Strukturasi dan Konstruksi Sosial. Malang: UIN Maliki Press, 2010, hlm. 7-8

13 Wawan, Djunaedi dan Iklilah Muzayyanah, Pendidikan Islam Adil Gender di Madrasah. Jakarta: Pustaka STAINU, 2008, hlm. 17-31 
masyarakat maupun keluarga yang umumnya menganggap kedudukan laki-laki lebih tinggi dibandingkan dengan perempuan.

3. Marginalization adalah menempatkan seseorang karena jenis kelaminnya sebagai pihak yang tidak dianggap penting dalam faktor ekonomi, sekalipun perannya sangat krusial. Marginalization merupakan keadaan untuk memiskinkan salah satu jenis kelamin karena perannya dalam berbagai bidang tidak dianggap penting sehingga secara financial tidak mampu berkembang.

4. Violence adalah segala bentuk perbuatan tidak menyenangkan yang ditujukan kepada pihak lain, baik dalam bentuk fisik maupun psikis. Kekerasan ini merupakan hal yang harus diatasi karena angka kekerasan yang terjadi secara umum maupun secara khusus terjadi di lingkungan jumlahnya dari tahun ke tahun mengalami peningkatan.

5. Double Burden adalah sebuah situasi yang menyebabkan seseorang harus menanggung beban kerja berlipat. Beban kerja berlipat ini biasanya terjadi bagi perempuan yang bekerja. Perempuan yang umumnya bekerja selain memiliki kewajiban menyelesaikan pekerjaannya, juga akan memiliki peran dan tugasnya dalam menyelesaikan segala urusan rumah tangganya. Hal demikian tidak selalu ditemui pada seorang laki-laki yang umunya hanya memiliki tugas dan tanggung jawabnya dalam pekerjaannya karena segala urusan rumah tangga sudah dianggap menjadi tugas dan kewajiban perempuan.

Bias gender dalam pendidikan adalah realitas pendidikan yang mengunggulkan satu jenis kelamin tertentu sehingga menyebabkan ketimpangan gender.14 Berbagai bentuk kesenjangan gender yang terjadi dalam berbagai bidang kehidupan masyarakat, terlihat juga dalam dunia

\footnotetext{
${ }^{14}$ Asrorah Hanun, Sosiologi Pendidikan, Surabaya: Kopertais Press, 2008, hlm 178.
} 
pendidikan, bahkan proses dan institusi pendidikan dipandang berperan besar dalam mensosialisasikan dan melestrikan nilai-nilai dan cara pandang yang mendasari munculnya berbagai ketimpangan gender dalam masyarakat.

Pada dasarnya untuk mengatasi permasalahan bias gender dalam pendidikan memang bukan hal yang mudah untuk dilakukan, hal ini karena anggapan masyarakat yang sudah melekat adalah tentang tugas dan peran laki-laki dan perempuan. Dengan demikian untuk dapat mengatasi bias gender dalam bidang pendidikan tentunya diawali dari keluarga sebagai unit pertama yang mengajarkan tentang gender. Keluarga diharapkan mampu memberikan keadilan dalam memperlakukan anak-anaknya, bukan karena jenis kelamin tertentu tetapi lebih memperlakukan anak-anak selayaknya sebagai manusia yang memiliki kekurangan dan kelemahannya bukan dilihat dari jenis kelaminnya.

Sekolah sebagai institusi penting yang berperan sebagai lembaga untuk mentransfer nilai-nilai yang tidak bias gender juga berperan penting untuk dapat merubah pandangan masyarakat bahwa laki-laki dan perempuan hanyalah kodrat Tuhan yang tidak dapat dirubah kapanpun dan di manapun, akan tetapi peran dan fungsinya dalam kehidupan sosial jelas tidak dapat dilihat dari jenis kelamin yang dimilikinya saja. Sekolah perlu untuk merubah pandangan bahwa terdapat jurusan-jurusan dalam pendidikan yang cocok untuk laki-laki maupun perempuan, karena pemilihan bidang kajian keilmuwan tentunya bukan didasarkan pada jenis kelamin, melainkan sesuai dengan bakat dan kemampuannya masing-masing.

Pemerintah sebagai pembuat kebijakan publik selayaknya menetapkan kebijakan yang tidak bias gender dengan memberikan 
kesempatan bagi perempuan untuk berkembang lebih maju. Hal ini dapat dimulai dengan menghilangkan budaya patriarki, sistem kapitalisme dan memberikan akses dan kesetaraan antara kaum perempuan dan kaum lelaki dalam bidang pendidikan sehingga mempunyai peluang yang sama untuk mengakses lapangan pekerjaan dan berperan dalam berbagai bidang kehidupan.

Konsep merupakan istilah, pegungkapan abstrak yang digunakan untuk tujuan mengklasifikasikan atau mengkategorisasikan suatu kelompok dari suatu benda, gagasan atau peristiwa. ${ }^{15}$ Pemahaman konsep dalam mata pelajaran Ilmu Pengetahuan Sosial merupakan hal yang perlu dilakukan guru, karena konsep akan membentuk pemahaman dan sikap anak terhadap sesuatu. Penanaman konsep dapat dikatakan sebagai proses mengkategorisasikan, mengklasifikasikan, dan memberikan nama pada suatu objek. Penanaman konsep pada mata pelajaran Ilmu Pengetahuan Sosial dipelajari dengan efektif jika disertai dengan mengemukakan sejumlah contoh yang positif. Konsep-konsep yang sederhana tentu harus diajarkan secara benar sehingga konsep yang menuntut pemikiran dan pemahaman yang lebih tinggi dapat dipahami dengan lebih mudah. Konsep yang dipilih hendaknya mampu mengorganisasikan, mensintesiskan sejumlah hubungan, fakta-fakta spesifik dan gagasan-gagasan. Adapun kriteria pemilihan konsep dapat dilihat dari konsep yang mewakili secara tepat disiplin ilmu yang terkait, konsep yang bermakna, konsep yang memiliki kelayakan dan kepantasan, tahan lama dan memberikan keseimbangan dalam kedalaman materi yang diajarkan. Dengan pemberian konsep yang benar siswa nantinya akan mampu membuat generalisasi yang

15 Sardijo dkk, Pendidikan IPS di SD, Jakarta: Universitas Terbuka, 2009, h. 9 
menggambarkan tentang konsep gender yang benar. Adapun untuk mengajarkan konsep gender yang benar dapat dilihat dari tabel berikut ini:

Tabel 1 Penanaman Konsep Gender pada Mata Pelajaran IPS

\begin{tabular}{|c|c|c|}
\hline No & Konsep & Keterangan \\
\hline 1. & Keluarga & $\begin{array}{l}\text { a. Terdiri dari ayah, ibu dan anak } \\
\text { b. Memiliki peran yang saling } \\
\text { membantu dalam keluarga, } \\
\text { sehingga ayah bisa bekerja ibupun } \\
\text { juga dapat membantu dalam } \\
\text { mencari nafkah } \\
\text { c. Mengurus rumah merupakan } \\
\text { tugas bersama, sehingga tidak } \\
\text { hanya ibu tetapi juga dapat } \\
\text { dilakukan ayah } \\
\text { d. Mendidik anak merupakan tugas } \\
\text { bersama baik ayah maupun ibu } \\
\text { e. Peran anak dalam keluarga dapat } \\
\text { membantu ayah dan ibu terutama } \\
\text { dalam mengurus rumah, belajar } \\
\text { dan diberi ruang untuk bermain. }\end{array}$ \\
\hline 2. & Laki-laki & $\begin{array}{l}\text { a. Menjadi kepala keluarga } \\
\text { b. Menjadi seorang ayah }\end{array}$ \\
\hline 3. & Perempuan & $\begin{array}{l}\text { a. Menjadi pendamping bagi } \\
\text { kepala keluarga } \\
\text { b. Menjadi seorang ibu }\end{array}$ \\
\hline
\end{tabular}


Tabel tersebut menggambarkan bagaimana konsep tentang keluarga dan peran antara laki-laki dan perempuan di lingkungan keluarga. Konsep tersebut bisa diperluas terutama dalam lingkup pendidikan. Guru dapat memberikan contoh-contoh yang menggambarkan peran laki-laki dan perempuan di sekolah maupun masyarakat. Di lingkungan sekolah dapat diberikan contoh konkrit bahwa pemilihan jurusan kemudian tugas yang diberikan guru tidak memandang jenis kelamin, tetapi lebih ditekankan pada kemampuan anak. Pada realitanya dalam dunia pendidikan juga memberikan pemahaman yang menjadikan anak memiliki pemikiran terkotak-kotak bahwa jurusan tertentu hanya tepat untuk anak laki-laki dan jurusan yang lain juga merupakan jurusan yang tepat bagi perempuan. Misalnya jurusan teknik hanya cocok untuk laki-laki dan jurusan tata busana hanya tepat untuk perempuan.

Penyampaian materi yang diajarkan guru juga harus mampu memberikan gambaran bahwa gender berbeda dengan jenis kelamin, guru harus memberikan gambaran bahwa kondrat laki-laki dan perempuan bebeda dengan peran yang perlu dijalankan di lingkungan keluarga, sekolah maupun masyarakat. Hal-hal yang berkaitan dengan kodrat secara mutlak tidak dapat ditukar antara laki-laki dan perempuan, akan tetapi hal-hal yang berkaitan dengan peran dan fungsi laki-laki maupun perempuan adalah hal yang dapat dilakukan secara bersama dan saling membantu dalam pelaksanannnya.

Nilai gender yang ditanamkan oleh guru merupakan role model yang sangat penting di luar lingkungan keluarga anak. Disadari atau tidak, setiap orang termasuk guru mempunyai stereotif tentang sifat gender yang pantas. Persepsi yang membentuk stereotip gender akan disampaikan secara langsung atau tidak langsung kepada siswa, baik 
melalui aktivitas pembelajaran dalam kelas maupun dalam aktivitasnya dengan peserta didik. Fakta dalam proses pembelajan tertentu guru lebih banyak berinteraksi dengan anak laki-laki, tetapi dalam hal-hal tertentu lainnya guru lebih banyak berinteraksi dengan anak perempuan. Hal tersebut dapat dilihat dari contoh konkrit interaksi guru dengan anak laki-laki biasanya berkaitan dengan aktivitas fisik, sedangkan pada anak perempuan berkaitan dengan aktivitas yang tidak banyak melibatkan fisik.

Guru dalam proses pembelajaran harus mampu menggambarkan peran laki-laki dan perempuan baik dalam lingkungan keluarga, sekolah dan masyarakat. Hal tersebut dapat dilakukan guru dengan memberikan contoh konkrit perbedaan kodrat dan peran laki-laki maupun perempuan. Penanaman konsep dapat dilakukan dengan mengurangi stereotip gender dengan melakukan langkah-langkah sebagai berikut:

1. Menggunakan bahan ajar yang tidak bias dan tidak mengandung stereotip gender. Penyediaan bahan ajar ini juga telah disyaratkan oleh kurikulum yang ditetapkan oleh kementerian Pendidikan.. Bahan ajar ini yang dibaca murid akan terinternalisasi dalam diri siswa sebagai bagian dari pengetahuannya (kognisi) dan dalam sikap (afeksi), melalui model kognisi dalam budaya. Pengetahuan yang dimiliki seseorang akan berpengaruh terhadap sikap yang dimilikinya. Bahan ajar harus menyediakan kemungkinan untuk menunjukkan bahwa stereotip gender dapat dipertukarkan satu sama lain. Bahan ajar harus dimuati aspek-aspek yang terkait dengan budaya setempat, dan memberikan porsi yang seimbang yang terkait dengan perbedaan gender, apalagi jika menyangkut tokoh-tokoh dalam bidang tertentu yang disebut dalam buku ajar. Stereotip gender dalam buku ajar nampak dalam aktivitas dan atau profesi yang khas 
laki-laki dan perempuan. Misalnya "Andi bermain bola, Ani menyapu dihalaman, Ibu memasak di dapur, Bapak sedang membaca buku, Ayah sedang mencangkul di Sawah". Ilustrasi visual pada gambar dalam teksbook lebih sering menampilkan anak laki-laki jika dibandingkan dengan anak perempuan dan dalam banyak hal lebih beragam corak aktivitas lebih diberikan pada laki-laki. Jarang kita lihat ditampilkannya posisi seimbang dalam pembagian kerja yang lebih menunjukkan keberimbangan peran antara jenis gender. Melihat realitas tersebut, guru harus memberikan pemahaman konsep yang benar dengan memberikan contoh aktivitas dan pekerjaan laki-laki dan perempuan secara seimbang tidak memihak pada salah satu jenis kelamin saja.

2. Penggunaan teknik pembelajaran dan perlakuan yang tidak memperekuat stereotip gender. Dalam proses pembelajaran guru hendaknya menggunakan kalimat yang netral gender dan bahanbahan yang memperkuat kesetaraan gender.

3. Menggunakan pendekatan kerja kelompok dan menciptakan suasana komunitas yang lebih baik. Baik antara siswa laki-laki maupun siswa perempuan.

4. Pemberian contoh dalam pembelajaran IPS harus dipilih dua contoh kelompok stereotip yang berbeda, misalnya dengan menyebutkan pakar bidang ilmu dari laki-laki dan perempuan. Dalam pembelajaran IPS materi sejarah Indonesia, misalnya disebut pahlawan laki-laki dan perempuan dalam perjuangan fisik dan diplomasi secara seimbang. Dengan demikian siswa akan tahu bahwa kontribusi laki-laki dan perempuan merupakan hal yang sebanding. 


\section{SIMPULAN}

Bias gender berawal dari adanya aturan-aturan tertentu yang dituntut oleh masyarakat terhadap laki-laki maupun perempuan, bahkan institusi pendidikan dipandang berperan besar dalam menyuburkan nilai-nilai dan cara pandang yang mendasari munculnya berbagai ketimpangan gender dalam masyarakat.

Penamanan konsep gender dapat dilakukan guru dengan memberikan contoh-contoh yang menggambarkan peran laki-laki dan perempuan di sekolah maupun masyarakat. Di lingkungan sekolah dapat diberikan contoh konkrit bahwa pemilihan jurusan kemudian tugas yang diberikan guru tidak memandang jenis kelamin, tetapi lebih ditekankan pada kemampuan anak. Guru juga dapat memilih bahan ajar dan teknik pembelajaran maupun pembelajaran yang tidak memperkuat stereotip gender. Pemberian contoh dalam pembelajaran IPS harus dipilih dua contoh kelompok stereotip yang berbeda sehingga siswa akan tahu bahwa kontribusi laki-laki dan perempuan merupakan hal yang sebanding.

Penanaman konsep gender dalam mata pelajaran IPS harus dilakukan guru dengan memberikan gambaran bahwa gender berbeda dengan jenis kelamin, guru harus memberikan gambaran bahwa kondrat laki-laki dan perempuan bebeda dengan peran yang perlu dijalankan di lingkungan keluarga, sekolah maupun masyarakat. Halhal yang berkaitan dengan kodrat secara mutlak tidak dapat ditukar antara laki-laki dan perempuan, akan tetapi hal-hal yang berkaitan dengan peran dan fungsi laki-laki maupun perempuan adalah hal yang dapat dilakukan secara bersama dan saling membantu dalam pelaksanannnya. 


\section{DAFTAR PUSTAKA}

Djunaedi, Wawan dkk, Pendidikan Islam Adil Gender di Madrasah. Jakarta: Pustaka STAINU, 2008.

Hanun, Asrohah, Sosiologi Pendidikan, Surabaya: Kopertais Press, 2008.

Jhon M. Echol, dan Hasan Shadily, Kamus Besar Inggris-Indonesia, Jakarta: Gramedia Pustaka Utama, 2000.

Mansour, Faqih, Analisis gender dan Transformasi Sosial, Yogyakarta: Pustaka Pelajar, 2000.

Marhaeni, A. A. I. N, Perkembangan Studi Perempuan, Kritik, dan Gagasan Sebuah Perspektif untuk Studi Gender ke Depan. Jurnal Piramida dalam ejournal. unud.ac.id, 2008 diakses 15 Agustus 2017.

Mufidah Ch. Bingkai Sosial Gender: Islam, Strukturasi dan Konstruksi Sosial. Malang: UIN Maliki Press, 2010.

Muthaliin, Achmad, Bias Gender dalam Pendidikan, Surakarta: Muhamadiyah University Press, 2001.

Nugroho, Riant, Gender dan Administrasi Publik, Yogyakarta: Pustaka Pelajar, 2008.

Sapriya, Pendidikan IPS, Bandung: PT Remaja Rosdakarya, 2009.

Umar, Nasarudin, Argumen Kesetaraan Gender: Perspektif al-Qur'an, Jakarta: Paramadina, 2001. 